\title{
窒化アルミニウムおよび窒素を共添加した炭化ケイ素セラミックスのピエゾ抵抗効果
}

\author{
岡田 泰行, 林 秀考, 岸本 昭 \\ 岡山大学大学院自然科学研究科機能分子科学専攻, = 700-8530 岡山市津島中 3-1-1.

\section{Piezoresistance Properties of Silicon Carbide Ceramics Doped with Aluminum Nitride and Nnitrogen}

\author{
Yasuyuki Okada, Hidetaka Hayashi and Akira Kishimoto \\ Division of Chemistry and Biochemistry, Graduate School of Natural Science and Technology, Okayama University,
} 3-1-1 Tsushima-naka, Okayama 700-8530, Japan.

Received May 31, 2006

\begin{abstract}
SYNOPSIS
Evaluation samples of $\alpha$-silicon carbide ceramics were first fabricated by glass capsule HIP method using powder mixture of silicon carbide and aluminum nitride with various ratio. The resultant aluminum nitride added silicon carbide ceramics were doped with nitrogen by changing the post-HIP nitrogen gas pressure. The lattice parameter increased with the amount of adding aluminum nitride indicating that the incorporated aluminum substituted smaller silicon atoms. After post-HIP treatment, lattice parameter then decreased with nitrogen gas pressure. The piezoresistive coefficient increased with the addition of aluminum nitride, it further increased with the nitrogen doping pressure.
\end{abstract}

KEY WORDS

silicon carbide, HIP, piezoresistance, co-doping, donor, acceptor

\section{1 緒 言}

固体の歪みに伴う抵抗率変化をピエゾ抵抗効果と呼び, 歪 みの直接測定や固体の弾性変形領域での応力測定に用いられ る.こうした歪み抵抗素子としてはシリコン単結晶が用いら れる.これはシリコンがかなりの感度(ピエゾ抵抗係数)を有 するほか, 生産性や加工, 接合など半導体プロセスで培われ た技術をそのまま生かせるためである。

しかしながらシリコンは, $200^{\circ} \mathrm{C}$ 程度のわずかな温度上昇 でも, 弾性変形領域が著しく狭くなり, 通常必要な歪みを与 えると塑性変形を起こしてしまうため, 応力を取り除いても 残留歪みが残るなどの問題がある.また，さらに高温では酸 化により絶縁化してしまうという問題もある。このため, 検 知素子が $200^{\circ} \mathrm{C}$ 高温を直接検知する圧力センサーは実用化 されていない。

炭化ケイ素は耐熱性に優れ，高温においても機械強度が保 持されることから, 高温構造材料としての応用が期待されて いる. また，バンドギャップが $2.0 \sim 3.0 \mathrm{eV}$ と広いことから, ハイパワー用途や高温適用の半導体としても注目されている. 炭化ケイ素単結晶においても, シリコン単結晶同様のピエゾ
抵抗特性が報告されていたが”，単結晶の利用が経済的に不 利であり, 感度もシリコンに劣ることからこれまで使われて こなかった。

これに対し我々は, 安価に作製でき機械特性にも優れる多 結晶炭化ケ个素において, 単結晶と同等の感度を初めて報告 した ${ }^{2-8)}$.これをふまえ, 室温では, 汎用で高感度のシリコン 単結晶を用い, 高温では, 許容レベルではあるが低感度の多 結晶炭化ケイ素を使う,という使い分けの提案をしてきた ${ }^{4-6)}$. ただし，炭化ケイ素を用いるときのみ，信号増幅やノイズ除 去など特別な回路が必要という問題は依然として残る. そこ で，感度を高めることにより，シリコンと同じ処理回路を用 いることができるものと考えられる.

炭化ケイ素セラミックスに微量添加物を加えて感度向上を 図ることは, 高温特性を生かすことが出来るため新物質探索 に比べ有利である. また, 多結晶は添加物の効果を調べやす いとの利点もある.

これまで, 実用面で優れる多結晶炭化ケイ素で添加物の効 果を調べ, 感度向上への指針を得ることを目的で検討を行っ てきた. III族およびV族を独立に添加した系では，いずれも 
固溶限界までは, 感度(ピエゾ抵抗係数)が向上することを報 告している ${ }^{6,7,9)}$. しかし， $\mathrm{Al}$ と $\mathrm{N}$ 共添加の効果を調べたとこ ろ,これらの固溶によるホールと電子は独立にピエゾ抵抗効 果に寄与することなく相殺されることが分かった ${ }^{10)}$.

そこで本研究では, 予備焼結の段階で, 炭化ケイ素にIII-V 族化合物である窒化アルミニウムを添加し，ある程度焼結さ せた試料を, 窒素ガスを圧力媒体とした熱間静水圧加圧(HIP) 処理することにより,さらに窒素のみを導入した系を作製し， ピエゾ抵抗効果に及ぼす共添加の影響を検討した，今回，窒 化アルミニウムを添加した系では， $\mathrm{n}$ 型となり，窒素を気相 で導入したときよりも感度が高くなった. また, 窒化アルミニ ウム添加により感度が飽和したと思われた試料に窒素を気相 で導入するとさらに感度が向上したのでその結果を報告する．

\section{2 試料及び実験方法}

出発原料として $\alpha$ 型炭化ケイ素粉末 (屋久島電工件) を用 い, 窒化アルミニウム $(\mathrm{AlN} ; 0.2,0.4,0.6,0.8,1.0,3.0,5.0 \mathrm{wt} \%)$ (侏)トクヤ) を単独で所定量加え, 遊星ボールミル(フリッ チェ)により混合粉末を調製した。このとき，混合溶媒とし てエタノール, 混合媒体としてジルコニアボールを用いた. 乳鉢で凝集粒子を粉砕し, 280 meshの篩いにて粒径を整えた のち, 試料一個につき約 $0.70 \mathrm{~g}$ ずつ直径 $10 \mathrm{~mm}$ の円柱形成型 器に入れ，60-100 MPaの圧力で一軸加圧成型した. 得られた ペレットをポリエチレンパックに真空封入し，シリコーンオ イル中にて $350 \mathrm{MPa}$ の圧力で冷間静水加圧 (CIP) を行った.

CIP後, 得られた圧粉体を石英ガラス管に真空封止した.ア ルゴンガスを圧力媒体として $195 \mathrm{MPa}, 1950^{\circ} \mathrm{C}, 30$ 分の条件 での HIP処理により予備焼成した。次いで得られた予備焼結 体を今度はカプセルフリー法(無カプセル HIP法)にて, 窒素 ガスを圧力媒体として $1950^{\circ} \mathrm{C} ， 30$ 分の条件で再度 HIP 処理 することにより, 窒化アルミニウムに加え窒素を添加した焼 結体試料を得た。

得られた予備焼結体および共添加焼結体について,アルキ メデス法にて密度測定を行い，相対密度を求めた。また，そ れぞれの試料についてX線回折により結晶相の同定と格子定 数の測定を行った.

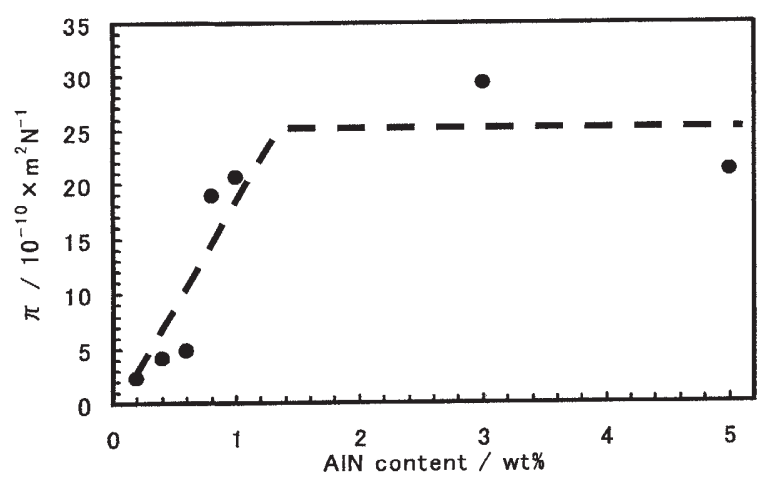

Fig.1 Change in piezoresistive coefficienet in SiC ceramics against aluminum nitride adding amount.
ピエゾ抵抗効果の測定で, 応力は力学試験機 (AGS-G 型 AUTO GRAPH (株)島津製作所製)を用い圧縮応力を印加し, 応 力印加方向に対し垂直方向の電場におけるピエゾ抵抗効果を エレクトロメータ(R8340 ULTRA HIGH RESISTANCE METER (㫼 ADVANTEST 製 )を用いた直流二端子法により評価した。 なおピエゾ抵抗効果の大きさの評価としてピエゾ抵抗係数 $\pi$ を単位応力あたりの抵抗率の変化率として下記の式から算出 した.

$$
\begin{aligned}
\pi= & \frac{\Delta \rho / \rho}{E \varepsilon} \\
& (\rho: \text { 抵抗率 } E: \text { ヤング率 } \varepsilon \text { : 歪み })
\end{aligned}
$$

各試料から得られた抵抗変化からピエゾ抵抗係数を算出し, ピエゾ抵抗係数の不純物濃度依存性について考察した。

\section{3 実験結果および考察}

$3.1 \mathrm{AlN}$ 添加によるピエゾ抵抗係数変化

III族及びV族元素化合物であるAINを単独で添加した試料 について検討を行った. 試料はいずれも相対密度 $92 \%$ 以上で あり,ピエゾ抵抗におよぼす密度の影響を考慮する必要はな いことを確認した. Fig.1 は, AlN 添加量に伴う SiC試料のピ エゾ抵抗係数の図である. AlN 添加量を増加させるに伴って ピエゾ抵抗係数の方も増加している.しかし1.0-3.0 wt\%添加 において値の増加が緩やかな変化となった。 そこで各試料の 格子定数を測定した結果を Fig. 2 に示す.その結果, $1.0 \mathrm{wt} \%$ 添加までは添加量を増加させるに伴って試料の格子定数の方 も増加している. しかし1.0-3.0 wt\%において格子定数の変化 が見られなくなっている.このことから固相からの $\mathrm{SiC} へ の$ AlN 添加では, 1.0-3.0 wt\%添加において固溶限界に到達して いると考えられる。

次に $\mathrm{AlN}$ 添加した $\mathrm{SiC}$ 試料のキャリア判定を行うために, $1 \mathrm{wt} \%$ 添加した試料においてホール測定を行った. その結果, 試料はn型である事を確認した。ここでFig.2より, 固溶限界 内と考えられる範囲では添加量を増加させるに伴い格子定数 も増加している。一般的に $\mathrm{SiC} へ$ の不純物の固溶は置換型で あることが知られている. 各元素の共有結合半径を考慮する

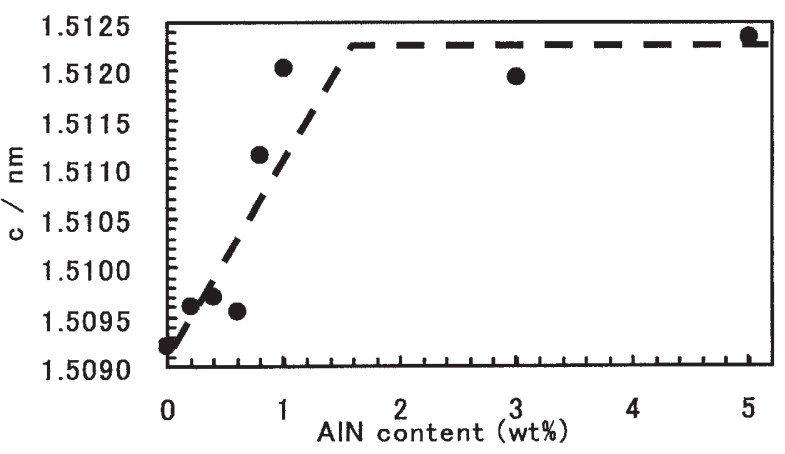

Fig.2 Change in lattice parameter in $\mathrm{SiC}$ ceramics against aluminum nitride adding amount. 


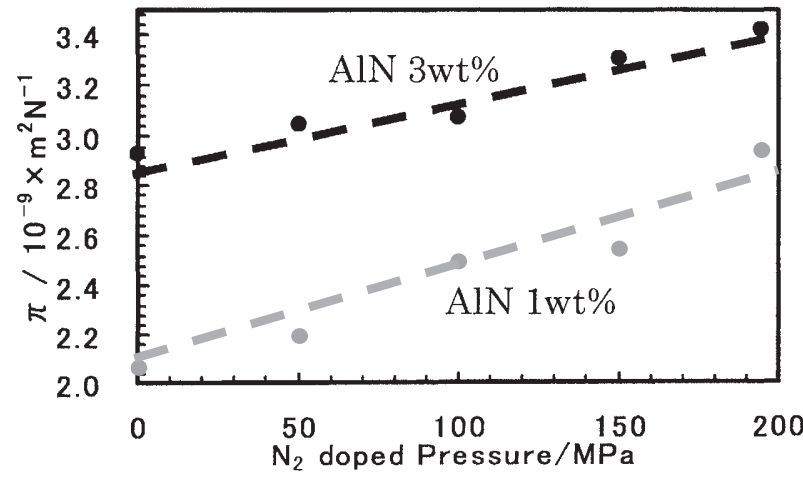

Fig. 3 Change in piezoresistive coefficienet in $1 \mathrm{wt} \%$ and $3 \mathrm{wt} \%$ aluminum nitride doped $\mathrm{SiC}$ ceramics against nitrogen doping pressure.

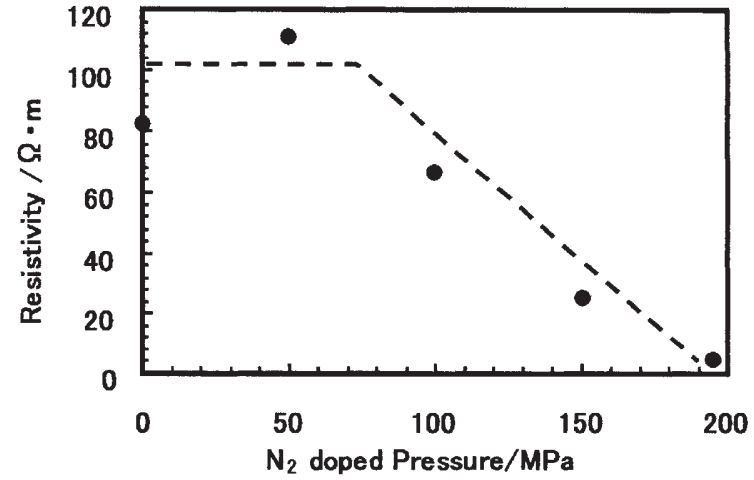

Fig.4 Change in resistivity without load in $1 \mathrm{wt} \%$ and $3 \mathrm{wt} \%$ aluminum nitride doped $\mathrm{SiC}$ ceramics against nitrogen doping pressure.

Table 1 Changes in lattice parameters (c-axis) in aluminum nitride doped silicon carbide after HIP treatment in nitrogen gas pressure of $195 \mathrm{Mpa}$.

\begin{tabular}{lc|}
\hline AlN addition/HIP pressure & Lattice parameter $/ \mathrm{nm}$ \\
\hline AlN (1 wt\%) & $1.5120(5)$ \\
AlN (1 wt\%)+195 MPa & $1.5095(2)$ \\
AlN (3 wt $)$ & $1.5119(5)$ \\
AlN (3 wt $\%)+195 \mathrm{MPa}$ & $1.5083(4)$ \\
\hline
\end{tabular}

と, $\mathrm{Si}(1.17 \AA)$ は共有結合半径の比較的近い $\mathrm{Al}(1.25 \AA)$ と, ま た C $(0.77 \AA)$ は $N(0.74 \AA)$ と置換固溶すると考えられる. そ のため $\mathrm{Al}$ が固溶すると格子定数は増加, Nが固溶すると減少 すると考えられる.このため Fig.2 で AINが固溶して格子定 数が増加するのは, 同量の AlNが固溶すると Nの置換固溶に よる格子定数の減少よりも, $\mathrm{A} 1$ 置換固溶による格子定数の増 加の方が変化の割合が大きいためであると考えられる.

$\mathrm{AlN}$ 添加では, $\mathrm{Al}$ とNは等量ずつ導入される. AlNの固溶 限界内で導電率が向上したのは, イオン化の割合や易動度の 関係から N添加の効果が大きいためと考えられ, ホール係数 が負つまり, $\mathrm{n}$ 型半導体となることから支持される.

$3.2 \mathrm{AlN}(1.0,3.0 \mathrm{wt} \%)$ 添加試料への気相 $\mathrm{N}_{2}$ 固溶

次に III族, V 族元素が共添加されている AlN 添加試料へさ らに気相から $\mathrm{N}_{2}$ 固溶をさせた結果を Fig.3に示す. 添加量 1.0 , $3.0 \mathrm{wt} \%$ の゙ちらの試料においても, 窒素圧力を増加していく につれて試料のピエゾ抵抗係数が増加した. また, AlN $3 w t \%$ における窒素圧力 $195 \mathrm{MPa}$ での窒素固溶を行った試料ではピ エゾ抵抗係数 $\pi=3.423 \times 10^{-9}\left(\mathrm{~m}^{2} \mathrm{~N}^{-1}\right)$ に達した. これは炭化ケ イ素でこれまで報告されているもつとも高い感度である.

Fig.4にはAlN 1 wt\%添加試料を各窒素圧力において焼結を 行った試料の比抵抗を示す. 焼結時の窒素压力が増加してい くにつれて試料の比抵抗は減少し, 窒素圧力 $195 \mathrm{MPa}$ での焼 結を行った試料では $\rho=4.12(\mathrm{~W} \cdot \mathrm{m})$ と, 窒素雲囲気での焼結
前後で比抵抗が格段に減少した。 またTable 1 に AlN (1.0, 3.0 $\mathrm{wt} \%)$ 添加試料の窒素雾囲気での焼結前後での格子定数变化を 示す.この結果, ぞちらの試料においても窒素圧力 $195 \mathrm{MPa}$ での焼結後には格子定数が減少している.このことから AlN 添加試料においても, 窒素雲囲気での焼結において試料へ窒 素固溶が行われていることを確認した. また, この気相から の更なる窒素固溶が生じることで, $\mathrm{n}$ 型半導体であった $\mathrm{AlN}$ 添加試料の感度向上が顕れたと考えられる.

これらの結果から, 固相での $\mathrm{Al}$ 添加試料 ( $\mathrm{p}$ 型半導体)へ気 相から窒素固溶を行った試料においてはピエゾ抵抗係数は減 少したが ${ }^{10)}$, 固相から III 族 + V 族化合物である AlNを添加し た試料 ( $\mathrm{n}$ 型半導体)へさらに気相から窒素固溶を行うとピエ ゾ抵抗係数増加, つまり試料の感度が向上する事を確認した. $\mathrm{AlN}(\mathrm{s})+\mathrm{N}_{2}(\mathrm{~g})$ 二二段ドーピングにより, AlNが大量に導入さ れ, 易動度の大きな電子伀導を使うことが出来るようになっ たため, ピエゾ抵抗効果が大きくなったものと考えられる.

注目すべきは, $\mathrm{N}_{2}(\mathrm{~g})$ の単独では150 MPaで, 窒素固溶が飽 和していたが, 二段ドーピングでは, 固溶量は圧力とともに 増加し続ける点である. $\mathrm{AlN}(\mathrm{s})$ として入った上に, $\mathrm{N}_{2}(\mathrm{~g})$ と しても導入されるために, Nの固溶量だけ考えると膨大であ る. 詳細はわからないが, $\mathrm{Al}$ の固溶で格子が広げられている 上に, Nが入ったためにNの固溶限が広がったと考えられる. 


\section{4 結言}

本研究では, III-V化合物である窒化アルミニウムを添加し てn型半導体とした炭化ケイ素セラミックス試料を，窒素雾 囲気中でポストHIPすることにより，窒素を共添加した系に ついて，ピエゾ抵抗効果に及ぼす影響を検討した。 AlN 添加 量増加に伴いピエゾ抵抗係数が増加することを確認した. 更 にAIN添加した試料においてn型半導体となることを確認し た. AlN添加試料へ気相からの窒素固溶を行うことで, ピエゾ 抵抗係数の増加を確認した．またこれにより,これまで本研 究室が検討を行ってきた炭化珪素圧力素子の中で最高感度の 試料の作製に成功した.この結果, 室温で汎用的に用いられ ているシリコンと同じ処理回路を用いることが可能になった.

\section{文献}

1) I.V.Rapatskaya, G.E.Rudashevskii, M.G.Kasaganova, M.I.Islitsin, M.B.Reifman and E.F.Fedotova: "Piezoresistance coefficients of n-type $\alpha$-SiC", Sov. Phys. Solid State, 9(1968) 2833-2835.

2) A.Kishimoto, A.Nakamichi and Y.Nakamura: "Monitoring of indantation and bending fracture in $\alpha$-SiC ceramics utilizing electrical methods", J. Mat. Sci., 34(1999)4233-4237.

3) G.Toyoguchi, S.Hirano, Y.Nakamura and A.Kishimoto: "Piezoresistive property of pressureless sintered silicon carbide ceramics", Trans. MRS-J, 25(2000)645-648.

4) G.Toyoguchi and A.Kishimoto: "Fabrication and Piezoresistive Effect of Silicon Carbide ceramics", Trans. MRS-J, 26(2001) 83-86.

5) G.Toyoguchi and A.Kishimoto: "Effect of aluminium addition on piezoresistance coefficient of beta-silicon carbide ceramics", J. Mat. Sci. Lett., 21(2002)101-103.

6) G.Toyoguchi and A.Kishimoto: "Role of aluminum on fabrication and piezoresistive effect of silicon carbide ceramics", Key Eng. Mat., 228-232(2002)251-254.

7) A.Kishimoto, G.Toyoguchi and H.Ichikawa: "Piezoresistivity of High-NICALON S SiC base fiber", J. Am. Ceram. Soc., 85 (2002) 479-480.

8) A.Kishimoto and Y.Numata: "Piezoresistance Properties of asilicon carbide ceramics doped with nitrogen", J. Jpn. Soc. Powder Powder Metallurgy, 51 (2004)346-349.

9) A.Kishimoto, D.Mutaguchi, H.Hayashi and Y.Numata: "High temperature piezoresistance properties of $6 \mathrm{H}-\mathrm{SiC}$ ceramics doped with trivalent elements", Mat. Sci. \& Eng. B., (in press).

10) A.Kishimoto, Y.Okada, D.Mutaguchi and H.Hayashi: "Piezoresistance properties of silicon carbide ceramics doped with trivalenet element and nitrogen", J. Jpn. Soc. Powder Powder Metallurgy, 52(2005)346-349. 